\title{
トリフェニルアミン系ホール輸送材料の合成と それらを用いた色素増感太陽電池特性
}

長尾幸徳*,·斉藤健志* ·土屋昌俊*・須田宗平*·有光晃二*・小澤幸三*

(2010年2月 8 日受付；2010年5月 14 日受理)

\begin{abstract}
要旨
トリフェニルアミン系ホール輸送材料としてフェニルエチル基，ジメチルアミノ基，アセチル基，アゾメチン結合などをもつ トリフェニルアミン誘導体を合成し，それらを用いた色素増感太陽電池やヨウ素錯体結晶を作製し，その特性を検討した。ま ず，電解質部分に合成したトリフェニルアミン誘導体を用いて固体色素増感太陽電池を作製し，その光電変換特性よりこれら のトリフェニルアミン誘導体がホール輸送材料として機能することを確認した。さらにこのホール輸送層にヨウ素をドープする ことで大きく光電変換特性が向上するトリフェニルアミン誘導体が見いだされ，ヨウ素ドープが性能向上の有効な手段であるこ とが示唆された。このヨウ素ドープの作用は酸化によるジイモニウム塩の形成に起因すると推定された。またフェニル基をもつ トリフェニルアミン誘導体はヨウ素と安定で電気伝導率の高い錯体結晶を生成することが見いだされ，有機半導体材料として有 望であることが示唆された。
\end{abstract}

\section{1. 緒 言}

トリフェニルアミン誘導体は有機EL素子のホール輸送材料 として多く用いられている。またこのような有機半導体材料の 有機トランジスタへの応用も盛んに研究されている。一方, 色 素増感太陽電池のうち比較的高い変換効率が得られているの は，ヨウ素系の電解質を用いる湿式（いわゆるグレッツェル型） 太陽電池で, 一般に Ru錯体色素, ヨウ素溶液, 多孔質二酸化 チタン層からなる1)。シリコン系太陽電池と比べ材料が安く, 製造工程も簡単なため, 低環境負荷の次世代型太陽電池として 注目され非常に多くの研究が行われている。通常, 高い光電変 換効率を示すヨウ素を含む溶液電解質が用いられるが，封止の 不完全性による溶媒の蒸発や事故時の液漏れなど耐久性や安全 性の面での問題点が指摘されている。そこで, 代わりに固体の 無機 $\mathrm{P}$ 型半導体のヨウ化銅 $(\mathrm{CuI})^{2)}$, 有機ホール輸送材料 $(\mathrm{HTM}))^{3)}$ を導入する試みがある。本研究では，新たなホール輸 送材料として，これまでの太陽電池に用いられている合成の複 雑な化合物ではなく単純な合成で得られる N,N,N', N'-テトラキ ス（p-アミノフェニル)-p-フェニレンジアミン（1）からトリフ エニルアミン誘導体 $2 \sim 4 \mathrm{c}$ ”を Scheme 1 に従って合成し, さら に1を出発原料として相当するアルデヒドを反応させ，アゾメ チン結合をもつトリフェニルアミン誘導体 $\mathbf{5 a} \sim \mathbf{c}$ 合成し (Scheme 2), それらを用いた色素増感太陽電池やヨウ素錯体結 晶を作製し，その特性を検討した。まず，ホール輸送材料とし て高い効率が報告されているヨウ化銅を用いて太陽電池作製条

*東京理科大学理工学部工業化学科

千葉県野田市山崎 2641（广278-8510)

$\dagger$ Corresponding Author, E-mail : cinagao@rs.noda.tus.ac.jp
件による光電変換特性への影響を検討した。次に，合成したト リフェニルアミン誘導体を用いて完全固体電解質色素増感太陽 電池を作製して光電変換特性を検討した。また，この類似化合 物はヨウ素をドープすることでELの性能が向上することが知 られているので太陽電池におけるヨウ素ドープの影響も検討し た。さらに，合成したトリフェニルアミン誘導体を用いてヨウ 素錯体を作製し，その電気伝導度などの性質も検討した。

\section{2. 実 験}

\section{1 試薬}

合成に用いた試薬は，すべて市販の 1 級もしくは特級品を使 用した。

\section{2 トリフェニルアミン系ホール輸送材料の合成}

2.2.1 トリフェニルアミン誘導体 2

トリフェニルアミン誘導体 $10.296 \mathrm{~g}(0.6 \mathrm{mmol})$ とフェノー ル $1.41 \mathrm{~g}(15 \mathrm{mmol})$, シクロヘキサノン $0.112 \mathrm{~g}(1.2 \mathrm{mmol})$, 水 素移動触媒として $10 \% \mathrm{Pd} / \mathrm{C} 0.3 \mathrm{~g}$ を加えて, $175^{\circ} \mathrm{C} て ゙ 5 \mathrm{~h}$ 還流擋 汼した。また，反応中で生じる水はトルエンを加えて共沸させ 取り除いた。反応後ガラスフィルターを使用しろ過を行うこと で Pd/Cを取り除き，ろ液からトルエン，フェノールを留去し た。その後，THFを用いた液体カラムクロマトグラフィーで精

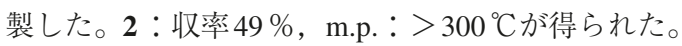

2 : ${ }^{1} \mathrm{H}-\mathrm{NMR}$ (DMSO-d $\left.6,300 \mathrm{MHz}\right) \delta 7.04-6.61(\mathrm{~m}, 40 \mathrm{H}$, $\operatorname{arom} . \mathrm{H}), 4.00(\mathrm{~s}, 4 \mathrm{H}, \mathrm{NH})$; IR $(\mathrm{KBr})\left(\mathrm{cm}^{-1}\right) 3389\left(v_{\mathrm{N}-\mathrm{H}}\right)$; $\operatorname{MS}(\mathrm{FAB})(\mathrm{m} / \mathrm{z}) 777\left(\mathrm{M}^{+}+\mathrm{H}\right) ; \operatorname{HRMS}(\mathrm{FAB})(\mathrm{m} / \mathrm{z})$ Calcd. for $\mathrm{C}_{54} \mathrm{H}_{44} \mathrm{~N}_{6} 776.3627$, Found : 776.3622 .

$$
\begin{aligned}
& 2.2 .2 \text { トリフェニルアミン誘導体 } \mathbf{3} \\
& \text { トリフェニルアミン誘導体 } 20.192 \mathrm{~g}(0.3 \mathrm{mmol}) \text { と水素化ナ }
\end{aligned}
$$



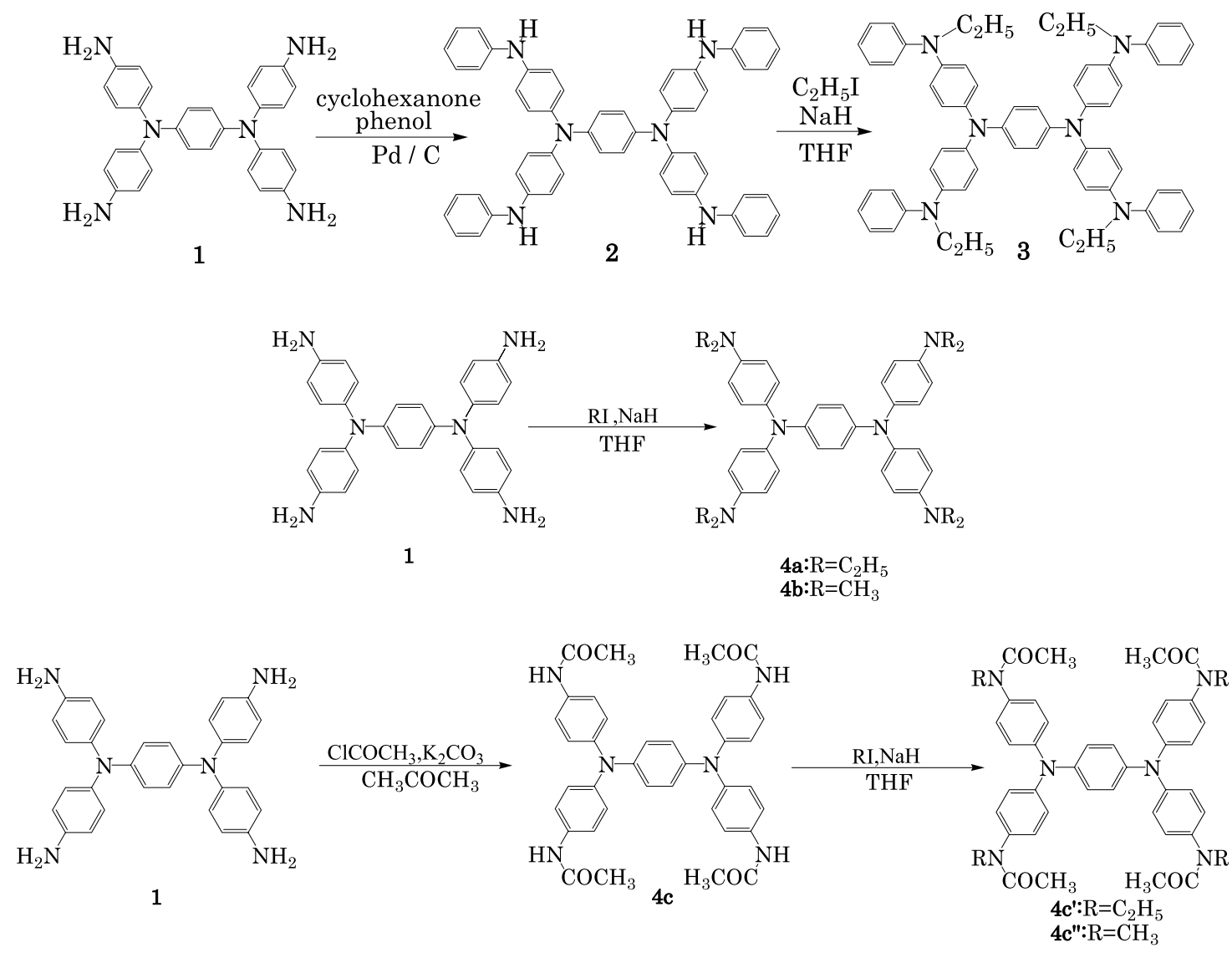

Scheme 1 Synthesis of triphenylamine derivatives $\mathbf{2} \sim \mathbf{4 c "}$.

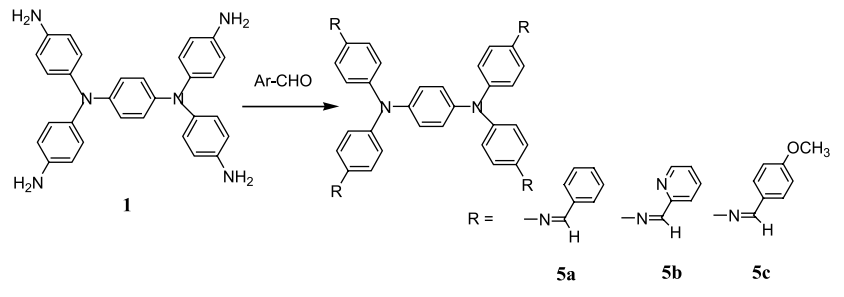

Scheme 2 Synthesis of triphenylamine derivatives $\mathbf{5 a} \sim \mathbf{c}$.

トリウム $0.048 \mathrm{~g}(1.2 \mathrm{mmol}), \exists ウ$ 化エチル $0.188 \mathrm{~g}(1.2 \mathrm{mmol})$ と脱水 $\mathrm{THF}$ を加え $80^{\circ} \mathrm{C}$ で $9 \mathrm{~h}$ 還流擋拌をした。反応終了後メ夕 ノールを加え, 水素化ナトリウムを分解させてから沈殿した固 体を吸引ろ過により取り出した。その後THFを用いた液体カラ ムクロマトグラフィーで精製した。3：収率 $55 \%$, m.p. : > $300{ }^{\circ} \mathrm{C}$ が得られた。

3 : ${ }^{1} \mathrm{H}-\mathrm{NMR}\left(\mathrm{DMSO}_{\mathrm{d}}, 300 \mathrm{MHz}\right) \delta 7.00-6.88(\mathrm{~m}, 40 \mathrm{H}$, arom. $\mathrm{H}), 1.11\left(\mathrm{t}, 12 \mathrm{H}, \mathrm{CH}_{3}\right), 3.70\left(\mathrm{q}, 8 \mathrm{H}, \mathrm{CH}_{2}\right) ; \mathrm{MS}$ (FAB) $(\mathrm{m} / \mathrm{z}) 889\left(\mathrm{M}^{+}+\mathrm{H}\right)$; HRMS (FAB) $(\mathrm{m} / \mathrm{z})$ Calcd. for $\mathrm{C}_{62} \mathrm{H}_{60} \mathrm{~N}_{6} 888.4879$, Found : 888.4883.

2.2.3 トリフェニルアミン誘導体 $\mathbf{4 a}, \mathbf{4 b}$

トリフェニルアミン誘導体 $10.384 \mathrm{~g}(0.6 \mathrm{mmol})$ と水素化ナ トリウム $0.192 \mathrm{~g}$ (4.8 mmol), ヨウ化アルキル（ヨウ化エチル $0.75 \mathrm{~g}(4.8 \mathrm{mmol}), \exists$ ウ化メチル $0.681 \mathrm{~g}(4.8 \mathrm{mmol}))$ と脱水 THFを加え $80^{\circ} \mathrm{C}$ で $10 \mathrm{~h}$ 還流擋挥をした。反応終了後メタノー ルを加え, 水素化ナトリウムを分解させて, 沈殿した固体を吸
引ろ過により取り出した。その後 THFを用いた液体カラムクロ マトグラフィーで精製した。4a：収率 $94 \%$ ，m.p. : 213〜 $215^{\circ} \mathrm{C}$ ，4b：収率 $70 \%$, m.p. : $271 \sim 274{ }^{\circ} \mathrm{C}$ が得られた。

4a : ${ }^{1} \mathrm{H}-\mathrm{NMR}\left(\right.$ DMSO- $\left._{6}, 300 \mathrm{MHz}\right) \delta 6.81-6.84(\mathrm{~m}, 8 \mathrm{H}$, arom. $\mathrm{H}), 6.49-6.61(\mathrm{~m}, 12 \mathrm{H}$, arom. $\mathrm{H}), 1.05(\mathrm{t}, 24 \mathrm{H}$, $\mathrm{CH}_{3}$ ), 3.27 (q, $16 \mathrm{H}, \mathrm{CH}_{2}$ ), 3.27 (q, 16H, $\mathrm{CH}_{2}$ ); $\mathrm{MS}(\mathrm{FAB})$ $(\mathrm{m} / \mathrm{z}) 697\left(\mathrm{M}^{+}+\mathrm{H}\right)$; HRMS $(\mathrm{FAB})(\mathrm{m} / \mathrm{z})$ Calcd. for $\mathrm{C}_{46} \mathrm{H}_{60} \mathrm{~N}_{6}$ 696.4879, Found : 696.4877 .

4b : ${ }^{1} \mathrm{H}-\mathrm{NMR}\left(\mathrm{DMSO}_{\mathrm{d}}, 300 \mathrm{MHz}\right) \delta 7.86-7.89(\mathrm{~m}, 8 \mathrm{H}$, arom.H $7.13-7.19(\mathrm{~m}, 12 \mathrm{H}, \operatorname{arom} . \mathrm{H}), 3.57(\mathrm{~s}, 24 \mathrm{H}$, $\left.\mathrm{CH}_{3}\right)$; MS (FAB) (m/z) $585\left(\mathrm{M}^{+}+\mathrm{H}\right) ; \operatorname{HRMS}(\mathrm{FAB})(\mathrm{m} / \mathrm{z})$ Calcd. for $\mathrm{C}_{38} \mathrm{H}_{44} \mathrm{~N}_{6}$ 584.3627, Found : 584.3621 .

\section{2 .4 トリフェニルアミン誘導体 $\mathbf{4 c}$}

トリフェニルアミン誘導体 $10.384 \mathrm{~g}(0.6 \mathrm{mmol})$ と塩化アセ チル $0.188 \mathrm{~g}(2.4 \mathrm{mmol})$, 炭酸カリウム $0.341 \mathrm{~g}(2.4 \mathrm{mmol})$ と

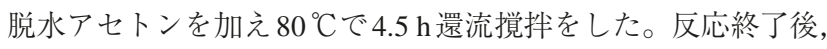
冷却し混合物を吸引ろ過により収集し，水により洗浄した。そ の後，THFにより洗浄した。4c：収率 $76 \%$, m.p. : 180〜 $182^{\circ} \mathrm{C}$ が得られた。

4c : ${ }^{1} \mathrm{H}-\mathrm{NMR}\left(\right.$ DMSO- $\left._{6}, 300 \mathrm{MHz}\right) \delta 7.45-7.48(\mathrm{~m}, 8 \mathrm{H}$, arom.H $), 6.83-6.93(\mathrm{~m}, 12 \mathrm{H}, \operatorname{aromH}), 9.86(\mathrm{~s}, 4 \mathrm{H}, \mathrm{NH})$, $2.00\left(\mathrm{~s}, 12 \mathrm{H}, \mathrm{COCH}_{3}\right)$; IR $(\mathrm{KBr})\left(\mathrm{cm}^{-1}\right) 3445\left(\mathrm{v}_{\mathrm{N}-\mathrm{H}}\right), 1664$ $\left(v_{\mathrm{C}=\mathrm{O}}\right) ; \operatorname{MS}(\mathrm{FAB})(\mathrm{m} / \mathrm{z}) 641\left(\mathrm{M}^{+}+\mathrm{H}\right)$; HRMS (FAB) $(\mathrm{m} / \mathrm{z})$ Calcd. for $\mathrm{C}_{38} \mathrm{H}_{36} \mathrm{O}_{4} \mathrm{~N}_{6} 640.2798$, Found : 640.2799. 
2.2.5 トリフェニルアミン誘導体 $4 \mathbf{c} ', 4 \mathrm{c}$ ”の合成

トリフェニルアミン誘導体 $4 \mathrm{c} 0.192 \mathrm{~g}(0.3 \mathrm{mmol})$ と水素化ナ トリウム $0.048 \mathrm{~g}(1.2 \mathrm{mmol}), \exists ウ$ 化アルキル (ヨウ化エチル $0.188 \mathrm{~g}(1.2 \mathrm{mmol}), \exists$ ウ化メチル $0.17 \mathrm{~g}(1.2 \mathrm{mmol}))$ と脱水 $\mathrm{THF}$ を加え $80{ }^{\circ} \mathrm{C}$ で $16 \mathrm{~h}$ 還流擋拌をした。反応終了後メ夕ノー ルを加え, 水素化ナトリウムを分解させ沈殿した固体を吸引ろ 過により取り出した。その後THFを用いた液体カラムクロマト グラフィーで精製した。4c'：収率 $68 \%$, m.p. : 182 $184{ }^{\circ} \mathrm{C}$, 4ce": 収率 $55 \%$, m.p. : $182 \sim 184^{\circ} \mathrm{C}$ が得られた。

4c' : ${ }^{1} \mathrm{H}-\mathrm{NMR}$ (DMSO-d, $\left.300 \mathrm{MHz}\right) \delta 7.09-7.23(\mathrm{~m}, 20 \mathrm{H}$, arom. $\mathrm{H}), 1.75\left(\mathrm{~s}, 12 \mathrm{H}, \mathrm{COCH}_{3}\right), 1.00\left(\mathrm{t}, 12 \mathrm{H}, \mathrm{CH}_{3}\right), 3.61$ $\left(\mathrm{q}, 8 \mathrm{H}, \mathrm{CH}_{2}\right)$; IR $(\mathrm{KBr})\left(\mathrm{cm}^{-1}\right) 1635\left(v_{\mathrm{C}=\mathrm{O}}\right) ; \mathrm{MS}(\mathrm{FAB})$ $(\mathrm{m} / \mathrm{z}) 753\left(\mathrm{M}^{+}+\mathrm{H}\right)$; HRMS (FAB) $(\mathrm{m} / \mathrm{z})$ Calcd. for $\mathrm{C}_{46} \mathrm{H}_{52} \mathrm{O}_{4} \mathrm{~N}_{6}$ 752.4050, Found : 752.4048 .

4c": ${ }^{1} \mathrm{H}-\mathrm{NMR}\left(\right.$ DMSO-d $\left._{6}, 300 \mathrm{MHz}\right) \delta 7.08-7.25(\mathrm{~m}, 20 \mathrm{H}$, arom.H), $1.79\left(\mathrm{~s}, 12 \mathrm{H}, \mathrm{COCH}_{3}\right), 3.12\left(\mathrm{~s}, 12 \mathrm{H}, \mathrm{CH}_{3}\right)$; IR $(\mathrm{KBr})\left(\mathrm{cm}^{-1}\right) 1634\left(v_{\mathrm{C}=\mathrm{O}}\right)$; MS (FAB) (m/z) $697\left(\mathrm{M}^{+}+\right.$ $\mathrm{H})$; HRMS (FAB) (m/z) Calcd. for $\mathrm{C}_{42} \mathrm{H}_{44} \mathrm{O}_{4} \mathrm{~N}_{6} 696.3424$, Found : 696.3423 .

\subsection{6トリフェニルアミン誘導体 $\mathbf{5 a}$}

トリフェニルアミン化合物 $10.236 \mathrm{~g}(0.5 \mathrm{mmol})$ とベンズアル デヒド $0.531 \mathrm{~g}(5 \mathrm{mmol})$ を加え, メタノール溶媒中で $7 \mathrm{~h}$ 還流攪 拌した。その後エバポレーションで溶媒留去を行い, シリカゲ ルカラムクロマトグラフィーによる精製を行い5aを単離した。 5a : 収率 $39 \%$, m.p. $237.1 \sim 237.6{ }^{\circ} \mathrm{Cが}$ 得られた。

${ }^{1} \mathrm{H}-\mathrm{NMR}\left(\mathrm{CDCl}_{3}, 300 \mathrm{MHz}\right) \delta 8.52(\mathrm{~s}, 4 \mathrm{H}), 7.88 \sim 7.91(\mathrm{~m}$, $8 \mathrm{H}), 7.47(\mathrm{t}, \quad J=3.3 \mathrm{~Hz}, 12 \mathrm{H}), 7.15 \sim 7.25(\mathrm{~m}, 16 \mathrm{H}), 7.06$ (s, 4H)

${ }^{13} \mathrm{C}-\mathrm{NMR}\left(\mathrm{CDCl}_{3}, 75 \mathrm{MHz}\right) \delta 158.59,146.45,146.07,142.75$, $136.47,131.10,128.74,128.65,125.21,124.38,122.09$ MS (FAB) $(\mathrm{m} / \mathrm{z}) 825[\mathrm{M}+\mathrm{H}]^{+}$

元素分析 Calcd. for $\mathrm{C}_{58} \mathrm{H}_{44} \mathrm{~N}_{6} \mathrm{C}: 84.44 \% \mathrm{H}: 5.38 \% \mathrm{~N}$ : $10.19 \%$

Anal. Found C : $84.31 \% \mathrm{H}: 5.27 \% \mathrm{~N}: 9.91 \%$

2.2.7トリフェニルアミン誘導体 $\mathbf{5 b}$

$10.236 \mathrm{~g}$ (0.5 mmol) と2-ピリジンカルボキシアルデヒド $0.535 \mathrm{~g}(5 \mathrm{mmol})$ 加え，メタノール溶媒中で $7 \mathrm{~h}$ 還流攪拌した。 その後エバポレーションで溶媒留去を行い, シリカゲルカラム クロマトグラフィーによる精製を行い 3 を単離した。 $5 \mathbf{b}:$ 収率 $46 \%$, m.p. $258.4 \sim 259.0{ }^{\circ} \mathrm{C}$ が得られた。

${ }^{1} \mathrm{H}-\mathrm{NMR}\left(\mathrm{CDCl}_{3}, 300 \mathrm{MHz}\right) \delta 8.70(\mathrm{~d}, J=4.2 \mathrm{~Hz}, 4 \mathrm{H}), 8.66$ $(\mathrm{s}, 4 \mathrm{H}), 7.21(\mathrm{~d}, J=7.8 \mathrm{~Hz}, 4 \mathrm{H}), 7.80(\mathrm{t}, J=7.8 \mathrm{~Hz}$, $4 \mathrm{H}), 7.29 \sim 7.37(\mathrm{~m}, 12 \mathrm{H})$

${ }^{13} \mathrm{C}-\mathrm{NMR}\left(\mathrm{CDCl}_{3}, 75 \mathrm{MHz}\right) \delta 158.46,154.83,149.62,146.63$, $145.18,142.71,136.60,125.58,124.83,124.27,122.54$, 121.70

HRMS (FAB) (m/z) Calcd. for $\mathrm{C}_{54} \mathrm{H}_{40} \mathrm{~N}_{10} 828.3437$ Found : $828.3433[\mathrm{M}]^{+}$

元素分析 Calcd. for $\mathrm{C}_{54} \mathrm{H}_{40} \mathrm{~N}_{10} \mathrm{C}: 78.24 \% \mathrm{H}: 4.86 \% \mathrm{~N}$ : $16.90 \%$

Anal. Found C : $77.92 \%$ H : $5.03 \%$ N : $16.80 \%$

\subsection{8トリフェニルアミン誘導体 $\mathbf{5 c}$}

$10.0944 \mathrm{~g}$ (0.2 mmol) と p-メトキシベンズアルデヒドを $0.2723 \mathrm{~g}(2 \mathrm{mmol})$ 加え, メタノール溶媒中で $7 \mathrm{~h}$ 還流攪拌し た。その後エバポレーションで溶媒留去を行い, シリカゲルカ ラムクロマトグラフィーによる精製を行い $5 \mathrm{c}$ を単離した。

5c : 収率 $64 \%$, m.p. 232.7-233.4 ${ }^{\circ} \mathrm{C}$ が得られた。

${ }^{1} \mathrm{H}-\mathrm{NMR}\left(\mathrm{CDCl}_{3}, 300 \mathrm{MHz}\right) \delta 8.44(\mathrm{~s}, 4 \mathrm{H}), 7.84(\mathrm{~d}, J=8.7$ $\mathrm{Hz}, 8 \mathrm{H}), 7.12 \sim 7.22(\mathrm{~m}, 16 \mathrm{H}), 7.03(\mathrm{~s}, 4 \mathrm{H}), 6.98(\mathrm{~d}, J=$ $8.7 \mathrm{~Hz}, 8 \mathrm{H}) 3.87(\mathrm{~s}, 12 \mathrm{H})$

${ }^{13} \mathrm{C}-\mathrm{NMR}\left(\mathrm{CDCl}_{3}, 75 \mathrm{MHz}\right) \delta 162.10,158.00 .146 .71 .145 .74$, $142.69,130.31,129.51,125.00,124.39,124.27,121.97$, 114.16, 55.41

HRMS (FAB) (m/z) Calcd. for $\mathrm{C}_{62} \mathrm{H}_{52} \mathrm{~N}_{6} \mathrm{O}_{4} 944.4050$ Found : 944.4050 [M] $]^{+}$

元素分析 Calcd. for $\mathrm{C}_{62} \mathrm{H}_{52} \mathrm{~N}_{6} \mathrm{O}_{4} \mathrm{C}: 78.79 \% \mathrm{H}: 5.55 \% \mathrm{~N}$ : $8.89 \%$

Anal. Found C : $78.42 \%$ H : $5.49 \%$ N : $8.87 \%$

\section{3 測定}

${ }^{1} \mathrm{H}-\mathrm{NMR}$ スペクトルはJEOL JNM-AL300型により $\mathrm{CDCl}_{3} や$ DMSO-d 6 を溶媒として測定した。MSスペクトルはJEOL Mstation JMS-700型により，IRスペクトルはJASCO FT/IR-410 型により KBr 錠剤法で測定した。サイクリックボルタンメトリ 一は日厚計測製回転リングディスク電極装置PRDE-1でジクロ ロメタン中支持電解質 tetrabutylammonium tetrafluoroborate $\left(\mathrm{TBABF}_{4}\right)$ と $\mathrm{Ag} / \mathrm{AgCl}$ 参照電極を用いて測定した。

\section{4 色素増感太陽電池の作製}

2.4 .1 湿式色素増感太陽電池の作製

大きさ $2.5 \times 1.0 \mathrm{~cm}$ の市販の導電性ガラス $(\mathrm{FTO})$ をアセトン で超音波バス中 $10 \mathrm{~min}$ 洗浄, 蒸留後の2-プロパノールで超音波 バス中 $10 \mathrm{~min}$ 洗浄をした。 $\mathrm{TiO}_{2}$ ペーストはP25（Degusa） $3.0 \mathrm{~g}$, アセチルアセトン $0.5 \mathrm{~mL}$, 蒸留水 $4.5 \mathrm{~mL}$, ポリエチレングリコ ール（分子量 20000） $0.6 \mathrm{~g}$ ，トリトンX-100 1 滴をジルコニアボ ール $(\phi 3 \mathrm{~mm}) 49 \mathrm{~g}$ ともにテフロン製の容器に入れ $2 \mathrm{~h}$ 容器を 振とうし， $\mathrm{TiO}_{2}$ 粒子を分散させたペーストを作製した。そし て，スキージ法により導電性ガラス上にペーストの塗布を行っ た。電気炉を用い大気中 $480^{\circ} \mathrm{C} て ゙ 30 \mathrm{~min}$ 保持することで焼成を 行った。 $\mathrm{TiO}_{2}$ 電極が焼成後室温まで泠えるまで待ち, $\mathrm{TiO}_{2}$ 電極 を慎重に削り取り測定面積を決定した。この電極を電気炉に入 れ $130^{\circ} \mathrm{C} て ゙ 2 \mathrm{~h}$ 保持することで表面に吸着した水を取り除いた。 その後電気炉から電極を取り出し, 電極が熱いうちに色素であ る $\mathrm{Ru}$ ビピリジル錯体色素 $\left(\mathrm{N} 3\right.$ 色素 : $\left(\mathrm{RuL}_{2}(\mathrm{NCS})_{2} \cdot 2 \mathrm{H}_{2} \mathrm{O} \quad \mathrm{L}=\right.$ 2,2'-bipyridyl-4,4'-dicarboxylic acid) ) のエタノール溶液 $(3.0 \times$ $\left.10^{-4} \mathrm{~mol} / \mathrm{L}\right)$ 中に入れ， $24 \mathrm{~h}$ 浸漬した。これにより $\mathrm{TiO}_{2}$ の細孔 内に増感色素を化学吸着させた。電極に着いた余分な色素を工 タノールで洗い落とし, 自然乾燥させた。 $\mathrm{TiO}_{2}$ 電極のTBP (4t-ブチルピリジン）による表面修飾を行った後, 対極と色素吸 着させた $\mathrm{TiO}_{2}$ 膜の面を合わせエポキシ樹脂で封止を行った。精 製したヨウ素を用いLiI : $0.3 \mathrm{M}$, Iodine : $0.03 \mathrm{M}$, acetonitrile : $\mathrm{NMO}=9: 1 （ \mathrm{NMO}: 3$-methyl-2-oxazolidinone）の組成の溶液 電解質を調製し，シリンジを使用し対極と色素吸着させた $\mathrm{TiO}_{2}$ 膜との間に少量流し込んだ。このようにして素子を作製した。 


\subsection{2 完全固体型色素増感太陽電池の作製}

大きさ $2.5 \times 1.0 \mathrm{~cm}$ の市販の導電性ガラス $(\mathrm{FTO})$ をアセト ンで超音波バス中 $10 \min$ 洗浄, 蒸留後の2-プロパノールで超音 波バス中 $10 \mathrm{~min}$ 洗浄をした。この導電性ガラス上に, チタンテ トライソプロポキシド，ジエタノールアミンを2-n-ブトキシエ タノールに溶かした溶液を塗布, 仮焼き $\left(150^{\circ} \mathrm{C}, 10 \mathrm{~min}\right)$, 焼成 $\left(480^{\circ} \mathrm{C}, 30 \mathrm{~min}\right)$ を行うことで，バリヤ層として緻密な $\mathrm{TiO}_{2}$ 膜 の短絡防止層を作製した。 $\mathrm{TiO}_{2}$ ペーストはP25（Degusa） $3.0 \mathrm{~g}$, アセチルアセトン $0.5 \mathrm{~mL}$ ，蒸留水 $4.5 \mathrm{mL，ポリエチレングリコ}$ ール（分子量 20000） $0.6 \mathrm{~g}$ ，トリトンX-100 1滴をジルコニアボ ール（ $\phi 3 \mathrm{~mm} ） 49 \mathrm{~g}$ ともにテフロン製の容器に入れ $2 \mathrm{~h}$ 容器を 振とうし， $\mathrm{TiO}_{2}$ 粒子を分散させたペーストを作製した。そし て，スキージ法により短絡防止層を作製した導電性ガラス上に

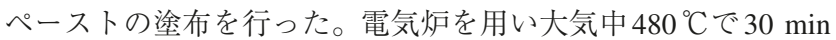
保持することで焼成を行った。 $\mathrm{TiO}_{2}$ 電極が焼成後室温まで泠え るまで待ち， $\mathrm{TiO}_{2}$ 電極を慎重に削り取り測定面積を決定した。 この電極を電気炉に入れ $130{ }^{\circ} \mathrm{C} て ゙ 2 \mathrm{~h}$ 保持することで表面に吸着 した水を取り除いた。その後電気炉から電極を取り出し, 電極 が熱いうちに色素である N3 色素の $\mathrm{EtOH}$ 溶液 $\left(3.0 \times 10^{-4} \mathrm{~mol} / \mathrm{L}\right)$ 中に入れ， $24 \mathrm{~h}$ 浸漬した。これにより $\mathrm{TiO}_{2}$ の細孔内に増感色素を 化学吸着させた。電極に着いた余分な色素をエタノールで洗い

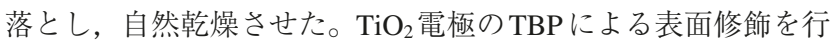
った。バイアルの中にホール輸送材料（HTM：0.1 wt％), 溶 媒 (クロロホルム), ドーパント $\left(\mathrm{Li}\left[\mathrm{CF}_{3} \mathrm{SO}_{2}\right]_{2} \mathrm{~N}\right): 13 \mathrm{mmol} / \mathrm{L}$, TBP : $0.13 \mathrm{~mol} / \mathrm{L})$ を入れ, 超音波処理をすることにより溶解 させ，この溶液をろ過したものをHTM溶液として使用した。 次に，窒素䨌囲気下としたグローブボックス中で加熱したホッ トプレートの上に多孔質 $\mathrm{TiO}_{2}$ 電極を置いた。次にHTM溶液を シリンジで少量取り，色素を吸着させた $\mathrm{TiO}_{2}$ 膜上に滴下し，溶 媒を揮発除去した。さらにヨウ素ドープするときは，ヨウ素 $0.1 \mathrm{~g}$ 入れたバイヤル中に素子をテープで貼り付けて垂らしておき， ふたをしてから約 $50^{\circ} \mathrm{C} て ゙ 1 \mathrm{~h}$ 加熱することでヨウ素ドープを行 った。炭素ペーストを塗布した対極（FTO）と色素吸着させ $\mathrm{HTM}$ を充填した $\mathrm{TiO}_{2}$ 膜の面を合わせ圧着しエポキシ樹脂で封 止した。このようにしてFig. 1のような素子を作製した。

2.4 .3 光電変換素子の光電流一電圧特性の測定

作製した色素増感太陽電池について光電流一電圧特性 $(\mathrm{I}-\mathrm{V})$ を調べた。測定は, 電流計（Advantest製TR8652）と電圧発生 器（Advantest製TR6142）を使用して行った。

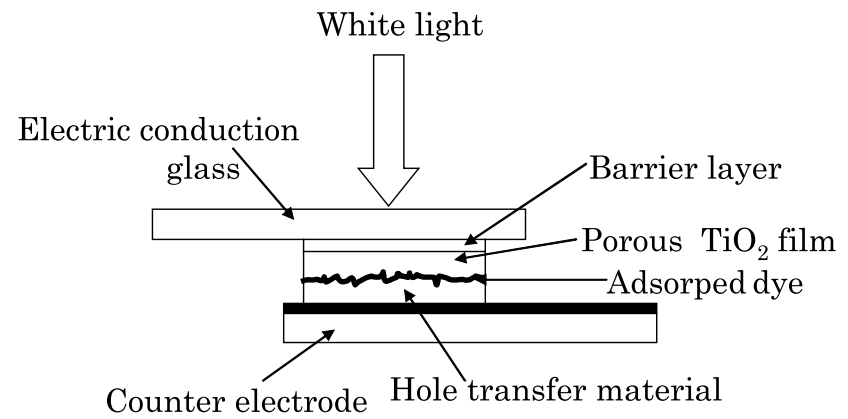

Fig. 1 Structure of photocell (solid-state).
光電流一電厈特性（I-V）は， $750 \mathrm{~W}$ のハロゲンランプを用い て白色光を照射して行った。ハロゲンランプの白色光は長波長 の照射エネルギーが強いので，IRカットフィルターを用いるこ とによって長波長領域の光を遮断し，太陽光のスペクトルに近 い照射光とした。

\section{5 ヨウ素錯体の作製}

2.5 .1 錯体結晶の作製

ホール輸送材料をアセトン，ヨウ素（昇華精製）を二硫化炭 素にそれぞれ溶かし，さまざまな混合比で混合し溶媒蒸発法に よりヨウ素錯体の結晶を作製した。錯体のホール輸送材料とヨ ウ素のモル比はヨウ素滴定と結晶のX線構造解析により求めた。

\subsection{2 電気伝導度の測定}

$0.025 \mathrm{~mm}$ 金線を導電性樹脂ドータイトXC-12（藤倉化成）で 結晶に端子付けし，定電圧発生装置Advantest R-6142，直流測 定装置Advantest R-8240，Pt 抵抗温度計付定電流発生装置 Advantest R-6142, Pt 抵抗温度計付電圧発生装置 Advantest R 6846を用いて測定した。作製した結晶は小さかったので直流 2 端子法により結晶の成長軸方向 $\mathrm{X}$ ，次に長い方向 $\mathrm{Y}$ ，短い方向 Zの3方向で電気伝導度を測定した。

\section{3. 結果および考察}

\section{1 トリフェニルアミン系ホール輸送材料の合成}

各合成したトリフェニルアミン誘導体は MS， ${ }^{1} \mathrm{H}-\mathrm{NMR} ， \mathrm{IR}$ スペクトルにより確認された。フェニルアミノ置換したトリフ エニルアミン誘導体 2,3 は融点が非常に高く $300{ }^{\circ} \mathrm{C}$ 以上であっ た。アルキルアミノ置換したトリフェニルアミン誘導体 $\mathbf{4 a}, \mathbf{b}$ では多少融点が低く，アセチルアミノ置換したトリフェニルア ミン誘導体 $4 c, c ’ ， c ”$ はらに低い融点を示した。アゾメチン 結合をもつトリフェニルアミン誘導体 $5 \mathbf{a} \sim \mathbf{c}$ はアルキルアミノ 置換した誘導体と同程度の融点を示した。有機溶媒への溶解性

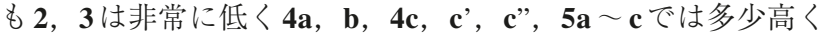
なった。

\section{2 色素増感太陽電池の光電変換特性}

3.2.1 湿式色素増感太陽電池の光電変換特性

N3色素を用いた湿式色素増感太陽電池によって基本的な構 成材料での光電変換特性を調べTable 1 に示した。文献1)の光 電変換特性と同程度の高い光電変換特性を示し，市販のチ夕二 アゾルを用いても作製できることが確認できた。この条件を基 にホール輸送材料を用いた完全固体型色素増感太陽電池の作製 を行い，ホール輸送材料部分の特性を検討した。

3.2.2 完全固体型色素増感太陽電池の光電変換特性

合成したトリフェニルアミン誘導体と，標準としてこれまで 報告のある $\mathrm{CuI}$ をホール輸送材料として用いた完全固体型色素増 感太陽電池（Fig. 1）を作製し，それらの光電変換特性を Table 2

Table 1 Properties of dye-sensitized solar cell using liquid electrolyte.

\begin{tabular}{ccccc}
\hline Dye & $\mathrm{J}_{\mathrm{SC}}\left(\mathrm{mA} \cdot \mathrm{cm}^{-2}\right)$ & $\mathrm{V}_{\mathrm{OC}}(\mathrm{V})$ & f.f. & $\eta(\%)$ \\
\hline $\mathrm{N}^{\mathrm{a}}{ }^{\mathrm{n}}$ & 18.0 & 0.70 & 0.53 & 6.7 \\
\hline
\end{tabular}

a) N3 dye : Lit. $^{1)} \quad \eta=7.12 \%$ 
Table 2 Properties of dye-sensitized solar cell using HTM.

\begin{tabular}{ccccc}
\hline $\mathrm{HTM}$ & $\mathrm{J}_{\mathrm{SC}}\left(\mathrm{mA} \cdot \mathrm{cm}^{-2}\right)$ & $\mathrm{V}_{\mathrm{OC}}(\mathrm{V})$ & f.f. & $\eta(\%)$ \\
\hline $\mathbf{1}$ & $1.5 \times 10^{-1}$ & 0.40 & 0.30 & $1.9 \times 10^{-2}$ \\
$\mathbf{2}$ & $3.8 \times 10^{-2}$ & 0.26 & 0.21 & $2.2 \times 10^{-3}$ \\
$\mathbf{3}$ & $8.4 \times 10^{-3}$ & 0.32 & 0.21 & $5.7 \times 10^{-4}$ \\
$\mathbf{4 a}$ & $6.7 \times 10^{-2}$ & 0.34 & 0.43 & $9.8 \times 10^{-3}$ \\
$\mathbf{4 b}$ & $1.8 \times 10^{-1}$ & 0.34 & 0.40 & $2.5 \times 10^{-2}$ \\
$\mathbf{4} \mathbf{c}$ & $8.9 \times 10^{-3}$ & 0.40 & 0.35 & $1.2 \times 10^{-3}$ \\
$\mathbf{4 c}$ & $4.9 \times 10^{-2}$ & 0.18 & 0.42 & $3.8 \times 10^{-3}$ \\
$\mathbf{4 c}$, & $3.1 \times 10^{-2}$ & 0.18 & 0.32 & $1.8 \times 10^{-3}$ \\
$\mathbf{5 a}$ & $9.3 \times 10^{-2}$ & 0.36 & 0.44 & $1.5 \times 10^{-2}$ \\
$\mathbf{5 b}$ & $1.0 \times 10^{-1}$ & 0.60 & 0.11 & $6.9 \times 10^{-3}$ \\
$\mathbf{5 c}$ & $2.1 \times 10^{-1}$ & 0.36 & 0.11 & $1.6 \times 10^{-2}$ \\
$\left.\mathbf{C u I}{ }^{2}\right)$ & $4.0 \times 10^{-1}$ & 0.06 & 0.15 & $0.36 \times 10^{-2}$ \\
\hline
\end{tabular}

a) $\mathrm{CuI}:$ Lit. $^{2)} \quad \eta=6 \%$

Table 3 Properties of dye-sensitized solar cell using iodine-doped HTM.

\begin{tabular}{ccccc}
\hline HTM & $\mathrm{J}_{\mathrm{SC}}\left(\mathrm{mA} \cdot \mathrm{cm}^{-2}\right)$ & $\mathrm{V}_{\mathrm{OC}}(\mathrm{V})$ & f.f. & $\eta(\%)$ \\
\hline $\mathbf{1}$ & $1.7 \times 10^{-1}$ & 0.29 & 0.16 & $7.8 \times 10^{-3}$ \\
$\mathbf{2}$ & $1.7 \times 10^{-1}$ & 0.22 & 0.26 & $9.9 \times 10^{-3}$ \\
$\mathbf{3}$ & $7.3 \times 10^{-1}$ & 0.44 & 0.33 & $1.1 \times 10^{-1}$ \\
$\mathbf{4 a}$ & $1.3 \times 10^{-1}$ & 0.38 & 0.30 & $1.5 \times 10^{-2}$ \\
$\mathbf{4 b}$ & $2.7 \times 10^{-1}$ & 0.40 & 0.34 & $3.7 \times 10^{-2}$ \\
$\mathbf{4 c}$ & $2.7 \times 10^{-2}$ & 0.52 & 0.34 & $4.8 \times 10^{-3}$ \\
$\mathbf{4 c}$, & $1.8 \times 10^{-2}$ & 0.40 & 0.32 & $2.3 \times 10^{-3}$ \\
$\mathbf{4 c} \boldsymbol{\mathbf { c }}$ & $3.8 \times 10^{-2}$ & 0.46 & 0.31 & $5.4 \times 10^{-3}$ \\
$\mathbf{5 a}$ & $5.4 \times 10^{-1}$ & 0.27 & 0.23 & $3.4 \times 10^{-2}$ \\
$\mathbf{5 b}$ & $9.3 \times 10^{-1}$ & 0.54 & 0.42 & $2.1 \times 10^{-1}$ \\
$\mathbf{5 c}$ & $7.2 \times 10^{-1}$ & 0.52 & 0.38 & $1.4 \times 10^{-1}$ \\
\hline
\end{tabular}

に示した。これらのトリフェニルアミン誘導体を用いた固体型 色素増感太陽電池は特殊な構造のホール輸送材料を用いた文献3) には及ばないが，すべて光電変換を示しホール輸送材料として 機能していることがわかる。光電変換効率 $\rceil$ はフェニルエチル アミノ基をもつ 3 がとくに低く，ジメチルアミノ基をもつ $\mathbf{4 b}$ と

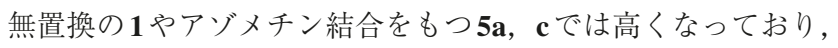
窒素原子上の置換基が光電変換効率に影響していることがわか る。標準の $\mathrm{CuI}$ の場合, 文献 2) に比べ光電変換効率が低い。 CuIでは作製後急速に変換効率が低下することが知られている。 溶液電解質を用いた色素増感太陽電池の光電変換特性と比べる と低いフィルファクター (f.f.) となっており, また短絡光電流 密度Jscも大きく低下している。低下の要因としては, 色素を 吸着している $\mathrm{TiO}_{2}$ 細孔や対極と結晶化した $\mathrm{CuI}$ の接触が不完全 となり, 電子やホールの移動が起こりにくいためと考えられる。 このように CuIの場合高い変換効率を得るには結晶化を抑える 特殊な作製方法が必要なことがわかる。また，トリフェニルア ミン誘導体を用いたセルでは, 同様の方法で作製したCuIのセ ルと同程度の光電変換特性を示すものも多数見られた。

3.2.3 ホール輸送材料層にヨウ素をドープした完全固体型色 素増感太陽電池の光電変換特性

ヨウ素ドープは，ホール輸送材料層まで作製した電極をヨウ 素とともに密閉した容器に入れ, 室温から $50{ }^{\circ} \mathrm{C} て ゙ 1 \mathrm{~h}$ 静置する

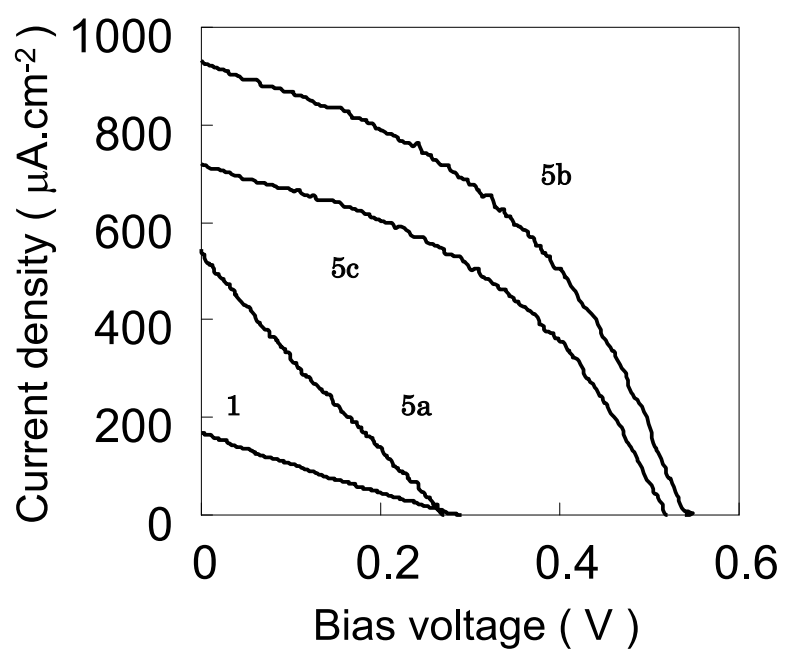

Fig. 2 Current density-voltage characteristics of HTM : $\mathbf{1}$ and $\mathbf{5 a} \sim \mathbf{c}$ devices.

ことで行った。これらの素子の光電変換特性をTable 3 に示し た。一例としてトリフェニルアミン誘導体 1 と $\mathbf{a} \sim \mathbf{c}$ を用いた ときの光電流一電圧特性（I-V）をFig. 2 に示した。Fig. 2 の電 流一電圧曲線よりヨウ素ドープ効果の少ない $\mathbf{1}, \mathbf{5 a}$ に比べ, ヨ ウ素ドープ効果の大きい $5 \mathbf{b}, \mathbf{c}$ では膨らみをもった電流一電圧 曲線を示し, 内部抵抗が減少しフィルファクター ffが大きくな ることがわかる。

Table 3 よりフェニルエチルアミノ基をもつ 3 とアゾメチン結 合をもつ $5 \mathbf{b}, \mathbf{c}$ がヨウ素ドープの効果が大きく, 最も高い光電 変換効率 $\eta$ 示した。これらの変換効率は特殊な構造のホール 輸送材料を用いた文献值 ${ }^{3)}$ よりも高い。フェニル基と電子供与 のエチル基やアゾメチン結合の効果が大きく, 電子吸引性のア セチル基を導入した $\mathbf{4 c} ， \mathbf{4 c}$ ， $4 \mathbf{c}$ ”では効果が低かった。このこ とからヨウ素ドープ効果も窒素原子上の置換基の影響を受ける ことがわかる。

このようにHTM層にヨウ素を吸着させることで光電変換特 性の向上が見られ，とくに短絡光電流密度Jscが向上し，ヨウ 素ドープにより光電変換特性の向上が期待できることがわかっ た。このようにヨウ素ドープが性能向上の有効な手段となり得 ることがわかり，その効果はホール輸送材料で一様ではないの でさらに効果の大きい材料の探索が期待できる。

\section{3 ヨウ素錯体結晶の電気伝導度}

ヨウ素ドープの影響がヨウ素錯体の形成能やその性質に由来 するか検討するため，ヨウ素錯体結晶を作製しその電気伝導度

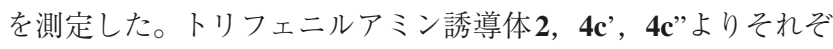
れヨウ素錯体結晶 2-I，4c'-I，4c”-Iが得られ，2-Iはアセトンー トルエン溶媒を用いて黒色針状晶，4c'-Iはアセトンー二硫化炭 素溶媒を用いて橙色板状晶, 4c”-I はアセトンー二硫化炭素溶 媒を用いて橙色板状晶が生成した。どの錯体もトリフェニルア ミン誘導体とヨウ素のモル比はヨウ素滴定とX 線結晶構造解析 より求めると $1: 4$ であった。

錯体結晶 $\mathbf{4} \mathbf{c}$ ”-I の成長軸方向（X方向）の電気抵抗率 $\rho$ と絶対 温度 Tについて $\log \rho$ と 1000/T の関係を Fig. 3に示す。Fig. 3 よ り温度が低くなると電気抵抗率が大きくなる半導体的挙動を示 


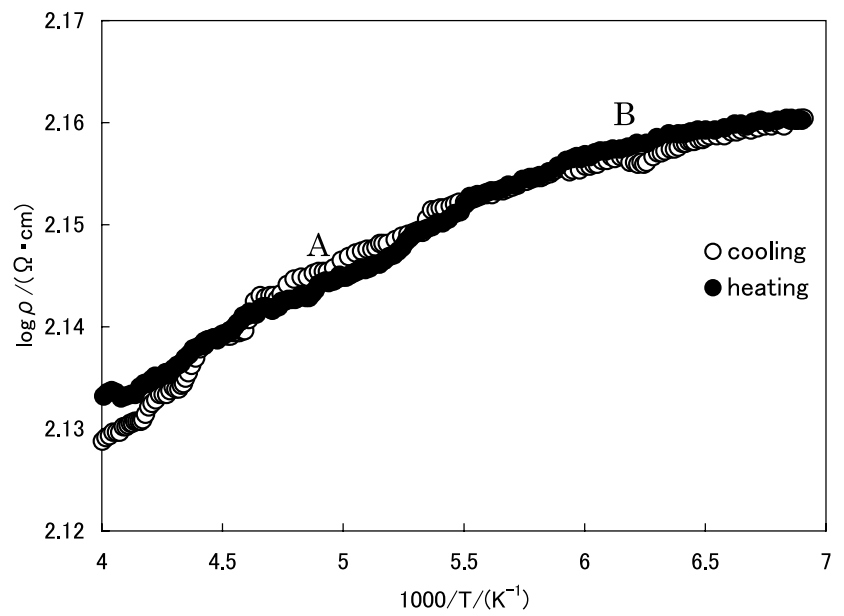

Fig. 3 Electric resistivity of crystal complex $\mathbf{4 c}$ "-I (X direction).

Table 4 Electric resitivity and activation energy for crystal complexes.

\begin{tabular}{ccccc}
\hline $\begin{array}{c}\text { Crystal } \\
\text { complex }\end{array}$ & Direction & $\begin{array}{c}\text { Electric } \\
\text { resitivity } \\
\rho 25(\Omega \cdot \mathrm{cm})\end{array}$ & $\begin{array}{c}\text { Activation energy. } \\
\text { Ea }\left(\times 10^{-3} / \mathrm{eV}\right) \\
\text { A region B region }\end{array}$ \\
\hline \multirow{2}{*}{ 2-I } & $\mathrm{X}$ & $1.1 \times 10^{1}$ & 3.2 & 2.2 \\
& $\mathrm{Y}$ & $1.5 \times 10^{2}$ & 5.5 & 3.0 \\
& $\mathrm{Z}$ & $3.1 \times 10^{3}$ & 5.8 & 3.1 \\
$\mathbf{4} \mathbf{4} \cdot-\mathrm{I}$ & $\mathrm{X}$ & $8.3 \times 10^{1}$ & 3.2 & 0.9 \\
& $\mathrm{Y}$ & $2.8 \times 10^{3}$ & 5.1 & 2.1 \\
& $\mathrm{Z}$ & $4.8 \times 10^{4}$ & 3.7 & 1.3 \\
$\mathbf{4}$ "'-I & $\mathrm{X}$ & $1.3 \times 10^{2}$ & 2.9 & 1.2 \\
& $\mathrm{Y}$ & $2.2 \times 10^{3}$ & 1.9 & 0.7 \\
& $\mathrm{Z}$ & $1.6 \times 10^{4}$ & 2.5 & 1.2 \\
\hline
\end{tabular}

すことがわかる。また高温付近 $\left(-20 \sim 90{ }^{\circ} \mathrm{C}\right)$ と低温付近 $\left(-90 \sim 130{ }^{\circ} \mathrm{C}\right)$ で傾きが変わることがわかる。ほかの方向 （Y，Z方向）でも同様の傾向を示した。またほかの錯体結晶 4c'-I，2-Iでも同様の傾向を示したので，高温付近を A 領域， 低温付近を B 領域として傾きより活性化エネルギーを求めた。 Table 4 に各錯体結晶における $25^{\circ} \mathrm{C}$ における電気抵抗率 $\rho_{25}$ と活 性化エネルギー Ea を示す。強い電子吸引性のアセチル基をもつ 錯体結晶 4c'-I，4c”-Iよりフェニル基をもつ錯体結晶 2-I のほう が電気伝導率が大きいことがわかる。この結晶は黒色なので分 子間が密になっていることが推定される。この安定な錯体を形 成し電気伝導度の大きい 2 に打いて, 太陽電池におけるヨウ素 ドープの効果は小さいので, ヨウ素ドープによる性能向上は安 定錯体形成による導電性向上とは関係なく，色素吸着した $\mathrm{TiO}_{2}$ や対極との接触に関与していることが示唆される。これらの錯 体は太陽電池の性能には関与しないが, 安定な錯体結晶を形成 するので有機トランジスタなど有機半導体材料への応用が期待 される。

\section{4 ヨウ素ドープによる吸収スペクトル}

ヨウ素ドープを行うと, 電流值Jscが増大するとともに光電 変換効率 $\eta$ 向上した。ホール輸送材料とヨウ素がどのような 相互作用を示すのかということを確認するために，ヨウ素ドー

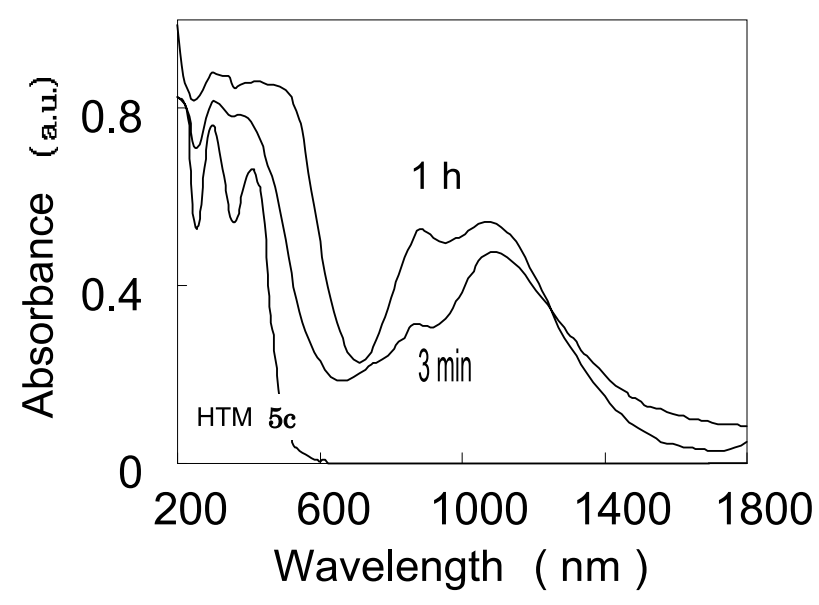

Fig. 4 Change of UV-vis-near IR absorption spectra of HTM 5c evaporated film by iodine doping.

プ効果の大きいトリフェニルアミン誘導体 $\mathbf{5 c}$ の蒸着膜にヨウ素 ドープを行い，そのヨウ素ドープ前後において吸収スペクトル を測定した。その結果をFig. 4 に示す。Fig. 4 より，ヨウ素ドー プを行うと, $3 \mathrm{~min}$ 後には近赤外領域に吸収があらわれ，さら にヨウ素ドープを続け $1 \mathrm{~h}$ 行うと, $890 \mathrm{~nm}$ での吸収が増大した。 このことから, $1090 \mathrm{~nm}$ での吸収はホール輸送材料 $\mathbf{5 c}$ の 1 電子 酸化後のピーク， $890 \mathrm{~nm}$ でのピークはホール輸送材料 $\mathbf{5 c}$ の 2 電 子酸化後のピークであると考えられる。この近赤外領域での吸 収は，ホール輸送材料 $\mathbf{5 b} に$ に打ても，ヨウ素ドープを行うこと で確認された。これにより，ホール輸送材料とヨウ素が塩（ジ イモニウム塩)を形成していることが文献より予想される4)。よ って前項のヨウ素錯体の形成能や電導度の向上が要因でないこ とから，ヨウ素ドープを行った素子の光電変換効率が高いの は，ホール輸送材料がヨウ素によって酸化され塩を形成し，色 素吸着した $\mathrm{TiO}_{2}$ や対極との接触が向上するため内部抵抗が減少 し，ホールや電子の移動が起こりやすくなり電流密度が増大し たと考えられる。

\section{5 ホール輸送材料のHOMO エネルギー準位}

合成したトリフェニルアミン誘導体 $5 \mathbf{a} ， \mathbf{5 b}, \mathbf{5 c}$ において，サ イクリックボルタンメトリーによる酸化還元ピークの測定から $\mathrm{HOMO}$ エネルギー準位を求め，標準水素電極（NHE）に換算し てあらわした。色素とトリフェニルアミン誘導体のHOMOエネ ルギー準位を Fig. 5 に示す。合成したホール輸送材料 5a， 5b, 5cは色素のHOMO エネルギー準位 ${ }^{5)}$ よりも高いHOMO エネル ギー準位を示した。この結果はホールの移動にともなって，ホ ール輸送材料 $5 \mathbf{a}, 5 \mathbf{b}, \mathbf{5 c}$ から色素への電子の移動が起こり得る ことがわかる。また，各ホール輸送材料を用いた素子において 取り出せる理想的な電圧は，ホール輸送材料の $\mathrm{HOMO}$ と $\mathrm{TiO}_{2}$ のフェルミ準位との差である。よって, ホール輸送材料 $\mathbf{5 b}$ が最 も高い電圧を取り出せることが示唆され, 実際の測定でも, ド 一パントを用いた系でも用いない系においても，ホール輸送材 料5bが最も高い值を示している。また, 電流密度Jscもホール 輸送材料5bが最も高い值を示していた。これは5b $の$ HOMO エ ネルギー準位は色素の HOMOエネルギー準位と最も近いことか ら，電子の移動が起こりやすくなったことに起因すると考えら 


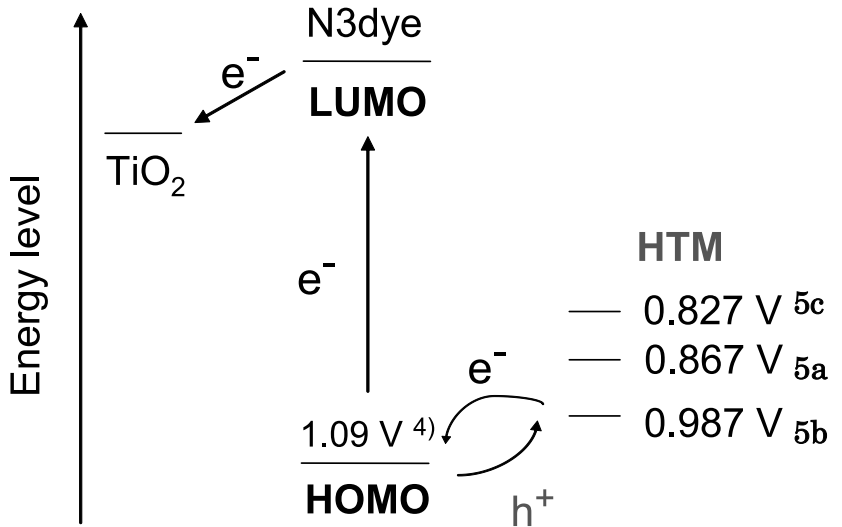

Fig. 5 Energy diagram for device structure (vs NHE).

れる。色素のエネルギー準位を変えた文献でもホール輸送材料 に近いほうが電子移動が起こりやすくなっている6)。ヨウ素ド ープにより一部塩を形成するためアモルファス状態になり内部 抵抗が減少し, さらに色素とホール輸送材料のエネルギー準位 が近いほうが電子移動が起こりやすいと考えられる。

\section{4. 結 論}

ホール輸送材料（HTM）としてフェニルエチル基，ジメチル
アミノ基，アセチル基，アゾメチン結合等をもつトリフェニル アミン誘導体を合成した。また，合成したHTMにより構成さ れる固体電解質を用いた色素増感太陽電池を作製した。この固 体電解質を用いた色素増感太陽電池では，光電変換特性を示し HTM として機能することが確認された。さらにHTM層にヨウ 素をドープすることで大きく光電変換特性の向上するトリフェ ニルアミン誘導体があり，ヨウ素ドープが性能向上の有効な手 段であることが示唆された。このヨウ素ドープの作用は酸化に よる塩の形成が起因すると推定された。またフェニル基をもつ トリフェニルアミン誘導体はヨウ素と安定で電気伝導率の高い 錯体結晶を生成した。

\section{文献}

1) B. O'Regan, M. Gratzel : Nature, 353, 737 (1991).

2) K. Tennakone, G. R. R. A. Kumara, I.R.M. Kottegoda, K. G. U. Kottegoda, K. G. U. Whjayontha, V. P. S. Perera : $J$. Phys. D : Appl. Phys, 31, 1492 (1998).

3) U. Bach, D. Lupo, P. Comte, J. E. Moser, F. Weissartel, J. Solbeck, H. Spreitzer, M. Graetzel : Nature, 395, 583 (1998).

4) S. J. Yeh : Electrochem. Commun., 5, 373 (2003).

5) K. Sayama, H. Sugihara, H. Arakawa : Chem. Mater., 10, 3825 (1998).

6) C. S. Kathikeyan, H. Wietasch, M. Thelakkat : Adv. Mater., 19, 1091 (2007).

\title{
Synthesis of Triphenylamine Hole Transport Materials and their Properties for Dye-Sensitized Solar Cell
}

\author{
Yukinori NagaO *, , Takeshi SAIto *, Masatoshi TsuchiYA *, Souhei SudA *, \\ Koji ARIMITSU * and Kozo KozaWA *
}

* Department of Pure and Applied Chemistry, Faculty of Science and Technology, Tokyo University of Science 2641 Yamazaki, Noda, Chiba 278-8510, Japan

$\dagger$ Corresponding Author, E-mail : cinagao@rs.noda.tus.ac.jp

(Received February 8, 2010 ; Accepted May 14, 2010)

\section{Abstract}

Triphenylamine derivatives having phenylethyl group, dimethylamino group, acetyl group, and azomethine bond were synthesized as triphenylamine-type hole transport materials and their properties for dye-sensitized solar cell and iodine complex were investigated.

The solid solar cell using synthesized triphenylamine derivatives instead of liquid electrolyte were examined, and the derivatives were confirmed to work as hole transport materials. The conversion efficiency of the cell using iodine doped hole transport layer were improved in some triphenylamine derivatives and the iodine doping seems to be a effective method for a high efficient cell. The iodine doping was assumed to form diiminium salt by the oxidation. Triphenylamine derivative having a phenyl group gave stabilized crystalline complex with iodine, which showed high electric conductivity.

Key-words : Hole transport material, Triphenylamine, Solid cell, Dye-sensitized solar cell, Iodine complex, Electric conductivity 